\title{
Agricultural Trade Diversity of India with Asean
}

\author{
Pranesh Pandey and Manesh Choubey*
}

Department of Economics, Sikkim University, GANGTOK, Sikkim, India

*Corresponding author: mchoubey@cus.ac.in (ORCID ID: 0000-0002-7992-4120)

Received: 03-04-2019

Revised: 07-07-2019

Accepted: 22-08-2019

\begin{abstract}
The ASEAN is India's fourth-largest trading partner after the EU, the US and China. Considering the significance of trade relation between India and ASEAN, the present study has been conducted with an objective to analyse the diversity in agricultural trade between India and ASEAN nations. The study has incorporated HS-2 digit codes to classify agricultural products and selected products falling under 01 to 24 chapters, which are agricultural products. Time series data of trade from 2001 to 2015 has been used in the present analysis. To see the importance of ASEAN as a major trading partner, shares of India's trade with ASEAN relative to world has been computed. It is apparent from the result that India's import from ASEAN is more than its export for the entire period. Simpsons Index of Diversity has been used to know the degree of diversification in agricultural trade between the two trading partners. The findings concluded that India exports of agricultural products are comparatively diversified with ASEAN compared to its import. The result suggests that there is stability in agriculture export earnings of India from ASEAN which in long run can contribute to the Economic growth.

Highlights

( India exports of agricultural products are diversified with ASEAN compared to its import which leads to stability in income earning for economic growth.
\end{abstract}

Keywords: Composition, Diversity, Agricultural Trade, Simpsons Index of Diversity

Agriculture has remained the largest source of employment, GDP, exports and foreign exchange earnings in many developing countries (Moïsé et al. 2013). Economic Survey 2013 revealed that India's global ranking for agricultural-exports is tenth. The share of India's agricultural exports and imports in the world agriculture trade in 2013-14 were 2.69 per cent and 1.31 per cent, respectively (Annual report 2015, Ministry of Agriculture, GOI).

India and ASEAN members are natural partners in trade and the ties date back to hundreds of years. India's partnership with the ASEAN members began with India becoming a sectoral dialogue partner at ASEAN meet in 1992 as an initial step towards India's 'Look East' policy. In 1996 India became full dialogue partner of ASEAN. Free Trade Area was established between India-ASEAN in 2009 and FTA in goods became effective from 2010. Latest is the FTA in services and investment signed- by all ASEAN nations with India. According to the ASEAN statistics (2013), India is among the top ten trade partners with ASEAN. The ASEAN is India's fourth-largest trading partner after the EU, the US and China. India's share to total ASEAN trade accounts 2.7 per cent in 2013 which grew from just 0.7 per cent in 1993. In the ASEAN market the processed food stuff, beverages, tobacco and other value-added products exported by India have the massive demand. Among various farm products imported from the ASEAN, animal and vegetable fats and oils are dominating the scenario (Renjini et al. 2017). Hence, trade of India with ASEAN in general and agriculture trade in particular appears to be pertinent.

David Richardo, through comparative advantage theory concluded that economic growth is possible 
AESRA

via trade specialization. That means a country should specialize and concentrate in producing those products where it has comparative advantage and export them (Salvatore, 1998). This study has been supported by many studies including Grossman and Helpman (1990), Gallardo (2005) and Riaz (2010). Unlike trade specialization theory of Richardo, many studies advocated trade diversification. The study which argued that countries with more diversified exports generally experiences faster economic growth includes Herzer and Lehnmann, (2006), Agosin (2007), Samen (2010), Anwesha and Rajat (2013) and Lugeiyamu (2016).

Basically, export diversification is defined as the changing of a country's export structure and composition. This diversity is achieved by changing the patterns of export or through innovation and technology. Export diversification is to widen the range of products that a country exports as stated by Dennis and Shepherd (2007). According to Ali et al. (1991), and Herzer and Lehnman (2006), diversification in export usually occurs in two dimensions i.e. horizontal and vertical diversification.

Horizontal diversification of exports is an increment of products available for exports which are from the same sector. Horizontal diversification usually prevent price fluctuation and thus brings stability in export earning as some sector experiences volatility in prices as was observed by Herzer and Lehnmann, (2006) and Samen (2010). While, vertical diversification of exports is a shift of products available for export from primary sectors production to secondary and to tertiary sector.

According to Poverty Matthee and Naudé (2008), vertical diversification takes place when new technologies are introduced and make use of them as a value addition in the form of processing and marketing. Moreover, it brings stability in export earning as in international marker, prices of manufactured exports are less fluctuating compared prices of primary exports (Ali et al. 1991).

Both horizontal and vertical export diversifications can produce positive results for a country's economic growth, but their performances have different dependencies on the technology, marketing and skills. Vertical diversification requires more advanced technology, sophisticated policies, skills and initial capital investment relative to the horizontal diversification ${ }^{1}$.

Nabi and Dhami (2013) analyzed India's agriculture Export Performance in Pre and Post WTO Regime (time series analysis from 1980-81 to 2009-10). The study cleared that the impact of WTO on India's primary product export performance was positive. This result is consistent with Raju (2010), Thomas and Sheikh (2011), and Kaur et al. (2012). However, and Raju (2010) argued that the gap between imports and exports have been widening and suggested the government should work out strategies to increase its exports and decrease the gap. Chauhan (1999) studied that liberalization of the trade policy of India enhanced its trade relationship with the ASEAN region, especially Singapore and Malaysia. This findings are consistent with Francis (2011), who concluded that in 2008, a total 10 per cent of India's exports were absorbed by the ASEAN-5 countries (Singapore, Indonesia, Malaysia, Thailand and Vietnam).

The study with respect to the composition of various agricultural exporting commodities of India has been studied by Shinoj and Mathur (2008) Shinoj (2009), Thomas and Sheikh (2011), Kanaka and Chinadurai (2012) and Banga et al. (2012). Their study declared declining trend in tea and coffee due to tough competition in the global market. While Shinoj (2009) concluded that in spite of pursuing favorable economic policies by both the parties, trade in agriculture has lagged behind other sectors as is evident from the low rates of growth and plummeting share of agricultural exports and imports in the total. India is a major supplier of several agricultural commodities like tea, coffee, rice, spices, cashew, oil meals, fresh fruits, fresh vegetables, meat and its preparations and marine products to the international market (Kanaka and Chinadurai, 2012). However, the country faces severe competition from other major players in the field, both the existing and new entrants in the battle (Shinoj and Mathur, 2008).

An attempt to study the composition and diversity of India's agricultural trade were narrow. Since, most of the study undertaken were a commodity

${ }^{1}$ Lugeiyamu, Eric Justinian (2016) Is Export Diversification a Key Force to Africa's Economic Growth? Cross-Country Evidence. Master's Thesis, Department of Economics, Jonkoping university, International business school, p.4 para (4) 
specific (Bardhan, 2007 and Shinoj, 2009) or it was too broader which included total trade (Sharma, 2015). Therefore, the main objective of the present study is to examine the changing scenario of composition and diversity in agriculture trade of India with ASEAN.

\section{MATERIALS AND METHODS}

Time series data pertaining from period 2001 to 2015, both Export and Import of India with individual ASEAN nations and world as a whole (in US dollar) has been used in the present analysis. It was retrieved from ITC data base (compiled from DGCIS and UN-COMTRADE).

\section{Agricultural Products}

HS-2 codes (Harmonized System- 2 digit codes) have been used in the present study to classify agricultural products. The Harmonized System (HS) is an international nomenclature defined by the World Customs Organization (WCO) for the classification of products. The study selected the products which falls under 01 to 24 chapters and termed as Agricultural Products. The product details which are divided into four sections are shown in Table 1.

\section{Analytical Tools}

To study the share of export and import of India's agricultural products out of its total trade with the

Table 1: Classification of Agricultural Products

\begin{tabular}{lcl}
\hline Sections & HS-2 digit codes & Agricultural products \\
\hline 01 & Live animals \\
02 & Meat and edible meat offal \\
1. Live animals; animal products & 03 & Fish and crustaceans, molluscs and other aquatic invertebrates \\
& 04 & $\begin{array}{l}\text { Dairy produce; birds' eggs; natural honey; edible products of animal } \\
\text { origin, not elsewhere specified or included }\end{array}$ \\
& 05 & Products of animal origin, not elsewhere specified or included \\
\hline 06 & Live trees and other plants; bulbs, roots and the like; cut flowers and \\
& ornamental foliage \\
& 07 & Edible vegetables and certain roots and tubers \\
& 09 & Edible fruit and nuts; peel of citrus fruit or melons \\
10 & Coffee, tea, mate and spices \\
11 & Cereals \\
12 & Products of the milling industry; malt; starches; inulin; wheat gluten \\
2. Vegetable Products & industrial or medicinal plants; straw and fodder \\
& 13 & Lac; gums, resins and other vegetable saps and extracts \\
& & Vegetable plaiting materials; vegetable products not elsewhere \\
& specified or included \\
\hline
\end{tabular}

3. Animal or vegetable fats and oils and their cleavage products; prepared edible fats; animal or vegetable waxes

\begin{tabular}{lll}
\hline & 16 & $\begin{array}{l}\text { Preparations of meat, of fish or of crustaceans, molluscs or other } \\
\text { aquatic invertebrates }\end{array}$ \\
& 17 & Sugars and sugar confectionery \\
4. Prepared foodstuffs; beverages, & 18 & Cocoa and cocoa preparations \\
spirits and vinegar; tobacco and & 19 & Preparations of cereals, flour, starch or milk; pastry cooks' products \\
manufactured tobacco substitutes & 20 & Preparations of vegetables, fruit, nuts or other parts of plants \\
& 21 & Miscellaneous edible preparations \\
& 22 & Beverages, spirits and vinegar \\
& 23 & Residues and waste from the food industries; prepared animal fodder \\
& 24 & Tobacco and manufactured tobacco substitutes \\
\hline
\end{tabular}

Animal or vegetable fats and oils and their cleavage products; prepared edible fats; animal or vegetable waxes

Sources: WCO, 2015. 
AESRA

world as a whole, the following formula has been used;

$$
s_{i}^{y}=\frac{x_{i}^{y}}{t^{y}}
$$

Where, $s_{i}{ }^{y}=$ share of export/import of the $i^{\text {th }}$ agricultural Products for $y^{\text {th }}$ year, $x_{i}^{y}=$ value of export/import of $i^{\text {th }}$ agricultural products for $y^{\text {th }}$ year, $t^{y}=$ value of total agricultural export/import for $y^{\text {th }}$ year.

To see the importance of ASEAN as a major trading partner, shares of India's trade with ASEAN relative to that of India's trade with world has been computed.

$$
s_{i}^{y}=\frac{x_{i a}^{y}}{x_{i w}^{y}}
$$

Where, $s_{i}^{y}=$ share of export/import of the $i^{\text {th }}$ agricultural products to/from ASEAN with respect to that of world for $y^{\text {th }}$ year, $x_{i a}{ }^{y}=$ value of export/ import of $i^{\text {th }}$ agricultural products to/from ASEAN for $y^{\text {th }}$ year, $x_{i w}{ }^{y}=$ value of export/import of $i^{\text {th }}$ agricultural Products to/from total world for $y^{\text {th }}$ year.

Simpsons Index of Diversity (SID) has been used in the present study to see the extent of diversity in agricultural trade of India with ASEAN.

$$
S I D=1-\sum_{i=1}^{n} w_{i}^{2} \text { and, } w_{i}=\frac{x_{i}}{\sum x_{i}}
$$

Where, $x_{i}=$ value of export/import of $i^{\text {th }}$ agricultural products and $w_{i}=$ proportionate value of export/ import of $i^{\text {th }}$ agricultural Products out of total agricultural export/import.

The value of Simpson's index of Diversity lies between 0 and 1 . If there is complete specialization, the index tends towards 0 and in cases of complete diversification, it tends towards 1 . Joshi et al. (2004), Singh et al. (2006), Shinoj (2007), Bardhan (2007) have used Simpsons Index of Diversity in their study to see the export/import diversity of agricultural products.

\section{RESULTS AND DISCUSSION}

\section{Composition of India's Agricultural Trade with ASEAN}

Earnings from the individual products as a share of total agricultural products exports have been shown in Table 2.

Table 2: Composition of Agricultural Export with ASEAN: Earnings from Individual Products as a

\begin{tabular}{|c|c|c|c|c|}
\hline HS code & 2001 & 2005 & 2010 & 2015 \\
\hline 01 & 0.04 & 0.00 & 0.00 & 0.00 \\
\hline 02 & 14.14 & 16.47 & 20.50 & 42.20 \\
\hline 03 & 8.50 & 8.84 & 8.30 & 17.61 \\
\hline 04 & 0.40 & 1.29 & 0.73 & 0.35 \\
\hline 05 & 0.39 & 0.06 & 0.16 & 0.25 \\
\hline 06 & 0.07 & 0.08 & 0.04 & 0.06 \\
\hline 07 & 3.95 & 4.44 & 5.00 & 2.56 \\
\hline 08 & 0.86 & 1.68 & 1.03 & 0.71 \\
\hline 09 & 2.69 & 4.26 & 6.26 & 7.61 \\
\hline 10 & 9.75 & 3.96 & 10.94 & 3.42 \\
\hline 11 & 0.69 & 0.68 & 0.31 & 1.07 \\
\hline 12 & 7.47 & 9.99 & 13.19 & 9.94 \\
\hline 13 & 1.56 & 1.40 & 0.58 & 0.35 \\
\hline 14 & 0.08 & 0.09 & 0.02 & 0.01 \\
\hline 15 & 2.11 & 2.40 & 1.55 & 1.65 \\
\hline 16 & 0.01 & 0.50 & 0.74 & 0.05 \\
\hline 17 & 14.19 & 1.32 & 1.50 & 3.69 \\
\hline 18 & 0.01 & 0.02 & 0.11 & 0.52 \\
\hline 19 & 0.46 & 0.76 & 0.52 & 0.25 \\
\hline 20 & 2.16 & 0.84 & 0.21 & 0.24 \\
\hline 21 & 1.08 & 0.90 & 0.82 & 0.92 \\
\hline 22 & 0.11 & 0.91 & 0.50 & 0.68 \\
\hline 23 & 28.11 & 35.34 & 23.80 & 4.30 \\
\hline 24 & 1.19 & 3.77 & 3.16 & 1.58 \\
\hline Total & 100 & 100 & 100 & 100 \\
\hline
\end{tabular}
Share of Total Agricultural Products Exports (per cent)

Sources: Authors calculation based on data generated from ITC data base (UN-COMTRADE).

The result discloses that the maximum export earnings of India were observed from HS-23 product (i.e. Residues and waste from the food industries; prepared animal fodder) from 2001 till 2010, their share ranged between 23.80 to 35.34 per cent though the trend is declining. But by 2015, its share decreased drastically to 4.30 percent. Even India's export earnings from world in this period for this product have declined. In 2015, HS-02 product i.e. Meat and edible meat offal dominated the scenario with 42.20 per cent share in total agricultural products exports. Significant share in export earning includes HS-03 (Fish and crustaceans, molluscs and other aquatic invertebrates), HS-12 (Oil seeds and oleaginous fruits; miscellaneous grains, seeds 
and fruit; industrial or medicinal plants; straw and fodder) HS-09 (Coffee, tea, mate and spices).

Table 3: Composition of Agricultural Import with ASEAN: values of individual products as a share of total agricultural products imports (per cent)

\begin{tabular}{ccccc}
\hline HS code & $\mathbf{2 0 0 1}$ & $\mathbf{2 0 0 5}$ & $\mathbf{2 0 1 0}$ & $\mathbf{2 0 1 5}$ \\
\hline 01 & 0 & 0 & 0 & 0 \\
02 & 0 & 0 & 0 & 0 \\
03 & 0.08 & 0.13 & 0.10 & 0.29 \\
04 & 0 & 0 & 0 & 0 \\
05 & 0.08 & 0.06 & 0.24 & 0.05 \\
06 & 0.03 & 0.03 & 0.03 & 0.10 \\
07 & 20.47 & 11.21 & 11.57 & 11.20 \\
08 & 0.69 & 4.90 & 0.94 & 1.35 \\
09 & 2.29 & 4.54 & 1.95 & 3.62 \\
10 & 0 & 0 & 0 & 0 \\
11 & 0.01 & 0.02 & 0.12 & 0.04 \\
12 & 0.16 & 0.40 & 0.28 & 0.56 \\
13 & 0.69 & 0.84 & 0.43 & 0.25 \\
14 & 0.04 & 0.07 & 0.04 & 0.19 \\
15 & 73.18 & 74.80 & 79.90 & 78.49 \\
16 & 0.01 & 0.01 & 0.01 & 0.00 \\
17 & 0.17 & 0.34 & 2.13 & 0.05 \\
18 & 0.39 & 0.35 & 0.76 & 1.03 \\
19 & 0.07 & 0.10 & 0.14 & 0.30 \\
20 & 0.10 & 0.13 & 0.16 & 0.15 \\
21 & 0.50 & 0.15 & 0.30 & 0.30 \\
22 & 0.07 & 0.16 & 0.11 & 0.21 \\
23 & 0.89 & 1.60 & 0.57 & 1.65 \\
24 & 0.06 & 0.17 & 0.19 & 0.17 \\
\hline Total & $\mathbf{1 0 0}$ & $\mathbf{1 0 0}$ & $\mathbf{1 0 0}$ & $\mathbf{1 0 0}$ \\
\hline
\end{tabular}

Sources: Authors calculation based on data generated from ITC data base (UN-COMTRADE).

The value of individual product as a share of total agricultural products imports have been shown in Table 3. India's import from ASEAN is dominated by HS-15 product (Animal or vegetable fats and oils and their cleavage products; prepared edible fats; animal or vegetable waxes) for entire period. It accounted 73.18 per cent in 2001 to 78.49 per cent in 2015. No imports were registered throughout the study period for products i.e. HS-01 (Live animals; HS-02 Meat and edible meat offal), HS-04 (Dairy produce; birds' eggs; natural honey; edible products of animal origin, not elsewhere specified or included).
It can be perceived from the result depicted from the Table 2 and 3 that India is basically an exporter of primary agricultural produce as the share of those products are very high. In contrast, ASEAN are exporting the processed and manufactured agricultural products to India. The idea that ASEAN is quite developed in terms of value added and manufactured services as compared to India can be generated from the study.

\section{Agricultural Trade of India with ASEAN: Product Wise}

India's agricultural exports to ASEAN as a share of agricultural exports to world with regard to individual product groups have been presented in Table 4.

Table 4: India's agricultural exports to ASEAN as a share of agricultural exports to world: product wise (per cent)

\begin{tabular}{|c|c|c|c|c|}
\hline HS code & 2001 & 2005 & 2010 & 2015 \\
\hline 01 & 13.18 & 0.20 & 0.19 & 0.03 \\
\hline 02 & 43.47 & 32.04 & 36.48 & 62.97 \\
\hline 03 & 5.82 & 6.81 & 12.12 & 24.93 \\
\hline 04 & 4.66 & 6.12 & 9.74 & 6.42 \\
\hline 05 & 8.07 & 1.77 & 6.93 & 20.28 \\
\hline 06 & 2.14 & 1.34 & 2.02 & 5.04 \\
\hline 07 & 14.25 & 9.34 & 16.40 & 14.44 \\
\hline 08 & 1.34 & 2.18 & 2.98 & 3.08 \\
\hline 09 & 2.75 & 5.36 & 9.87 & 16.83 \\
\hline 10 & 9.16 & 2.34 & 11.81 & 3.23 \\
\hline 11 & 12.39 & 23.54 & 12.91 & 23.45 \\
\hline 12 & 20.02 & 27.77 & 38.43 & 37.38 \\
\hline 13 & 5.64 & 3.94 & 2.81 & 2.06 \\
\hline 14 & 3.42 & 3.98 & 1.10 & 0.93 \\
\hline 15 & 9.20 & 8.55 & 6.86 & 11.50 \\
\hline 16 & 2.34 & 3.63 & 8.14 & 1.63 \\
\hline 17 & 33.53 & 19.16 & 4.57 & 17.24 \\
\hline 18 & 1.25 & 4.18 & 12.18 & 18.66 \\
\hline 19 & 8.38 & 7.35 & 6.64 & 3.21 \\
\hline 20 & 25.30 & 6.95 & 2.43 & 3.18 \\
\hline 21 & 6.47 & 5.95 & 8.25 & 10.69 \\
\hline 22 & 3.04 & 20.59 & 9.42 & 12.77 \\
\hline 23 & 52.79 & 49.50 & 36.38 & 26.02 \\
\hline 24 & 5.80 & 14.29 & 11.35 & 10.91 \\
\hline $\begin{array}{c}\text { Total } \\
\text { agriculture }\end{array}$ & 13.53 & 11.75 & 16.44 & 20.48 \\
\hline
\end{tabular}

Sources: Authors calculation based on data generated from ITC data base (UN-COMTRADE) 
The total agricultural export of India to ASEAN was accounted to be 13.53 per cent in the year 2001, which increased to 20.48 per cent in 2015. HS-02 (Meat and edible meat offal) ranked top in terms of export as compared to other products throughout the period except in the year 2010 where HS-12 dominated the scenario. HS- 12 (Oil seeds and oleaginous fruits; miscellaneous grains, seeds and fruit; industrial or medicinal plants; straw and fodder), HS- 23 (Residues and waste from the food industries; prepared animal fodder) also have a significant contribution in India's export basket to ASEAN throughout the study period.

Table 5: India's agricultural imports from ASEAN as a share of agricultural imports from world: product wise (percent)

\begin{tabular}{|c|c|c|c|c|}
\hline HS code & 2001 & 2005 & 2010 & 2015 \\
\hline 01 & 0 & 0.05 & 0.01 & 0 \\
\hline 02 & 14.63 & 7.77 & 0.88 & 6.70 \\
\hline 03 & 9.96 & 12.13 & 10.67 & 35.36 \\
\hline 04 & 0.71 & 0.38 & 0.04 & 0.05 \\
\hline 05 & 6.66 & 9.68 & 48.32 & 10.66 \\
\hline 06 & 29.91 & 14.45 & 15.68 & 42.33 \\
\hline 07 & 39.30 & 34.99 & 36.18 & 23.97 \\
\hline 08 & 3.04 & 11.53 & 4.16 & 3.47 \\
\hline 09 & 34.25 & 42.08 & 36.10 & 38.01 \\
\hline 10 & 0.14 & 0.70 & 0.08 & 0.20 \\
\hline 11 & 2.64 & 5.01 & 24.33 & 5.13 \\
\hline 12 & 6.89 & 10.82 & 10.33 & 12.97 \\
\hline 13 & 27.79 & 28.40 & 21.59 & 10.01 \\
\hline 14 & 33.04 & 40.46 & 29.46 & 52.62 \\
\hline 15 & 54.10 & 57.08 & 72.70 & 58.65 \\
\hline 16 & 19.48 & 6.70 & 19.84 & 6.46 \\
\hline 17 & 9.17 & 2.32 & 12.06 & 0.66 \\
\hline 18 & 40.83 & 28.48 & 38.81 & 39.46 \\
\hline 19 & 5.02 & 6.69 & 21.70 & 36.86 \\
\hline 20 & 10.90 & 12.05 & 15.24 & 16.15 \\
\hline 21 & 9.10 & 12.49 & 21.62 & 18.33 \\
\hline 22 & 4.96 & 1.30 & 2.83 & 2.92 \\
\hline 23 & 23.96 & 28.63 & 17.71 & 35.95 \\
\hline 24 & 16.81 & 17.77 & 43.21 & 29.24 \\
\hline $\begin{array}{c}\text { Total } \\
\text { agriculture }\end{array}$ & 41.44 & 37.77 & 47.03 & 37.46 \\
\hline
\end{tabular}

Sources: Authors calculation based on data generated from ITC data base (UN-COMTRADE).

It is evident from the analysis that India's import from ASEAN is more than its export to ASEAN for the entire period which ranged between 37.46 to
47.03 per cent, which has been shown in Table 5. For the entire period of consideration, HS-15 product (Animal or vegetable fats and oils and their cleavage products; prepared edible fats; animal or vegetable waxes) dominated the scenario with maximum import share ranged between 54.10 to 72.70 per cent. Even other products including HS-6, HS- 7, HS-9, HS-13, HS-14, HS-18, HS-19, HS-20, HS-21, HS-23 and HS-24 have an important contribution.

\section{Export Diversity of India with ASEAN}

By applying the Simpsons Index of Diversity, the result of export diversity of India with ASEAN with regard to agricultural products has been shown in Table 6.

Table 6: Export Diversity of India with ASEAN in Agricultural Products

\begin{tabular}{ccccc}
\hline Countries & $\mathbf{2 0 0 1}$ & $\mathbf{2 0 0 5}$ & $\mathbf{2 0 1 0}$ & $\mathbf{2 0 1 5}$ \\
\hline Brunei Darussalam & 0.70 & 0.76 & 0.76 & 0.68 \\
Cambodia & 0.62 & 0.60 & 0.42 & 0.69 \\
Indonesia & 0.77 & 0.62 & 0.71 & 0.69 \\
Lao PDR & 0.21 & --- & 0.00 & 0.36 \\
Malaysia & 0.81 & 0.82 & 0.84 & 0.79 \\
Myanmar & 0.78 & 0.78 & 0.47 & 0.45 \\
Philippines & 0.73 & 0.73 & 0.72 & 0.73 \\
Singapore & 0.78 & 0.81 & 0.92 & 0.89 \\
Thailand & 0.58 & 0.76 & 0.77 & 0.80 \\
Vietnam & 0.73 & 0.48 & 0.75 & 0.60 \\
ASEAN & $\mathbf{0 . 8 5}$ & $\mathbf{0 . 8 2}$ & $\mathbf{0 . 8 6}$ & $\mathbf{0 . 7 7}$ \\
\hline
\end{tabular}

Sources: Authors calculation based on data generated from ITC data base (UN-COMTRADE).

It has been observed that from year 2001 till 2015, at every interval the value of SID is approaching towards 1 with respect to the overall ASEAN nation. This indicates India exports of agricultural products were fairly diversified with ASEAN as a whole. Though, there is a fluctuation and declining trend as shown in Table 6 . With regard to the individual ASEAN nation, the country with whom India is exporting diversified agricultural produce was Malaysia with the value 0.81 followed by Myanmar and Singapore in the year 2001. But by 2015, with Singapore, India has exported diversified agricultural produce with the value 0.89 , followed by Thailand and Malaysia. This result designate India to be in a better position, as diversification in exports leads to stability in export earnings and 
on the whole, it can produce positive results for a country's economic growth as suggested by Herzer et al. (2006), Samen (2010) and Lugeiyamu (2016). It is worth mentioning here that agriculture price in the international market is volatile, so export diversification will help in export earnings stability of India.

\section{Import Diversity of India with ASEAN}

The result of import diversity of India from ASEAN with regard to agricultural products has been shown in Table 6. It is evident from the result that at every interval the value of SID is less than 0.50 with respect to the overall ASEAN nation. This indicates India imports of agricultural products are not diversified from ASEAN as a whole. There is also a declining trend from 0.42 in 2001 to 0.37 by the year 2015 as shown in Table 7 .

Table 7: Import Diversity of India in Agricultural Products with ASEAN

\begin{tabular}{ccccc}
\hline Countries & $\mathbf{2 0 0 1}$ & $\mathbf{2 0 0 5}$ & $\mathbf{2 0 1 0}$ & $\mathbf{2 0 1 5}$ \\
\hline Brunei Darussalam & - & - & - & - \\
Cambodia & - & 0.47 & 0.07 & 0.56 \\
Indonesia & 0.15 & 0.23 & 0.06 & 0.13 \\
Lao PDR & - & 0.00 & 0.40 & 0.48 \\
Malaysia & 0.04 & 0.10 & 0.11 & 0.03 \\
Myanmar & 0.02 & 0.03 & 0.06 & 0.08 \\
Philippines & 0.61 & 0.76 & 0.77 & 0.69 \\
Singapore & 0.85 & 0.84 & 0.82 & 0.77 \\
Thailand & 0.57 & 0.87 & 0.68 & 0.79 \\
Vietnam & 0.47 & 0.17 & 0.36 & 0.59 \\
ASEAN & $\mathbf{0 . 4 2}$ & $\mathbf{0 . 4 2}$ & $\mathbf{0 . 3 5}$ & $\mathbf{0 . 3 7}$ \\
\hline
\end{tabular}

Sources: Authors calculation based on data generated from ITC data base (UN-COMTRADE).

Regarding the individual ASEAN nation, it has been observed that Myanmar and Malaysia are those nations from ASEAN whose values were approaching towards 0 throughout the study period. This shows there is a fair amount of specialization in import from these nations. This result is consistent with Shinoj (2009) and EEPC India (2018) where large amount of imports from Myanmar and Malaysia were particularly from edible vegetables, pulses, wood products and palm oil respectively.

\section{CONCLUSION}

India is basically exporters of primary agricultural produce as the share of those products are very high. In contrast, ASEAN exported the processed and manufactured agricultural products to India. The idea that ASEAN is quite developed in terms of value added and manufactured services as compared to India can be generated from the study. It is evident from the analysis that India's import from ASEAN was more than its export to ASEAN for the entire period. HS-02 (Meat and edible meat offal) ranked top in terms of export as compared to other products throughout the period except in the year 2010 where HS-12 (Oil seeds and oleaginous fruits; miscellaneous grains, seeds and fruit; industrial or medicinal plants; straw and fodder) dominated the scenario. With respect to import, HS-15 product (Animal or vegetable fats and oils and their cleavage products; prepared edible fats; animal or vegetable waxes) dominated the throughout the study period. India exports of agricultural products were fairly diversified with ASEAN as a whole while import specialization of agriculture prevailed. This answer India's stability in export earnings and in general there is a positive sign of economic growth in long run until diversity in agriculture export reign.

\section{REFERENCES}

Agosin, M.R. 2007. Export Diversification and Growth in Emerging Economies. Working Paper No. 233., Departamento de Economía. Universidad de Chile.

Ali, R. Alwang, J. and Siegel, P.B. 1991. Is Export Diversification the Best Way to Achieve Export Growth and Stability? A Look at Three African Countries. Policy Research Working Paper Series 729. The World Bank.

Anwesha A. and Rajat A. 2013. Export diversification, composition, and economic growth: Evidence from cross-country analysis. The Journal of International Trade $\mathcal{E}$ Economic Development. Taylor E Francis Journals, 22(7): pp. 959-992, October.

Bardhan, D. 2007. India's Trade Performance in Livestock and Livestock Products. Ind. J. of Agri. Econ., 62(3).

Banga R. and Das A. 2012. Twenty Years of India's Liberalisation: Experiences and Lessons. United Nations Conference on Trade and Development. UNCTAD Publication. UNCTAD/OSG/2012/1.

Chauhan, K.P. 1999. India's Trade and Investment Relationship with ASEAN Countries: With Special Reference to Singapore and Malaysia. Ph.D. Thesis, South Asian Studies, Division Centre for South Central South East Asian and South West Pacific Studies, School of 
$\underset{\text { AESRA }}{\int_{1}}$ Pandey and Choubey

International Studies, Jawaharlal Nehru University, New Delhi.

Dennis, A. and Shepherd, B. 2007. Barriers to Entry, Trade Costs, and Export Diversification in Developing Countries. The World Bank Policy Research Working Paper. available at http://siteresources.worldbank.org/ INTTRADERESEARCH/Resources/544824-132009187 3839/8238146 -1320451708214/Dennis_paper.pdf.

EEPC India. 2018. India Pavilion at Agri Myanmar 2018. Yangon, Myanmar, 6-8 December 2018. Available at https://www. eepcindia.org/download/Circular-180926164928.pdf.

Francis, Smitha. 2011. The ASEAN-India Free Trade Agreement: A Sectoral Impact Analysis of Increased Trade Integration in Goods. Economic and Political Weekly, 46(02).

Gallardo, J.L. 2005. Comparative advantage, economic growth and free trade, Revista de Economia Contemporânea, 9(2): pp.313-335.

Grossman, G.M. and Helpman, E. 1990. Comparative Advantage and Log Run Growth. The American Economic Review, 80(4): 796-815.

Herzer, D. and Nowak-Lehnmann, D.F. 2006. What does export diversification do for growth? An econometric analysis. Applied Economics, 38(15): 1825-1838.

Joshi, P.K., Gulati, A., Badal, P.S. and Tewari, L. 2004. Agricultural diversification in South Asia: Pattern, determinants and policy implications. Economic and Political Weekly, pp. 2457-2467.

Kanaka, S. and Chinadurai, M. 2012. A Study of Comparative Advantage of Indian Agricultural Exports. Journal of Management and Science, 2(3).

Lugeiyamu, E.J. 2016. Is Export Diversification a Key Force to Africa's Economic Growth? Cross-Country Evidence. Master's Thesis, Department of Economics, Jonkoping university, International business school.

Matthee, M. and Naudé, W. 2008. Export Diversity and Regional Growth in a Developing Country Context: Empirical Evidence. Available at https://pdfs.semanticscholar. org/26e3/10ed4528b22e6bb61076fb2ebdb9a1d448b2.pdf .

Moïsé, E., Delpeuch, C., Sorescu, S., Bottini, N. and Foch, A. 2013. Estimating the Constraints to Agricultural Trade of Developing Countries. OECD Trade Policy Papers. OECD, France.
Nabi, T. and Dhami, J.K. 2013. Analysis of India's Agriculture Export Performance in Pre and Post WTO Regime. International Journal of Enhanced Research in Management $\mathcal{E}$ Computer Applications, 2(4): 1-5.

Raju, Sunitha. 2010. ASEAN - India FTA: Emerging Issues for Trade in Agriculture. Indian Institute of Foreign Trade. Available at http://agritrade.iift.ac.in/html/ Training/ASEAN\%20\%E2\%80\%93\%20India $\% 20$ FTA $\% 20$ \%20Emerging \%20Issues\%20for\%20Trade\%20in \%20 Agriculture/Sunita\%20Raju\%20mam.pdf

Riaz, B. 2010. Comparative Advantage, Exports and Economic Growth: An Issue of Causality, Master's Thesis, Department of Economics. Södertörns Högskola, Sodertorns University.

Salvatore, D. 1998. International Economics. $6^{\text {th }}$ Edition. Prentice Hall: New Jersey.

Samen, S. 2010. A Primer on Export Diversification: Key Concepts, Theoretical Underpinnings and Empirical Evidence. Growth and Crisis Unit, World Bank. Washington DC. https://blogs.worldbank.org/files/ growth/EXPORT_DIVERSIFICATION_A_PRIMER_ May2010\%281\%29.pdf.

Sharma, S.P. 2015. India's Exports Diversification - Crisscross Outcomes. Ph.D. Research Bureau. Ph.D. Chamber of Commerce and Industry, ISBN No. 9789384145224.

Shinoj, P. 2009. India-ASEAN Trade in Agriculture: Retrospect and Prospect. National Centre for Agricultural Economics and Policy Research. Policy Brief- 29.

Shinoj, P. and Mathur, V.C. 2008. Comparative Advantage of India in Agricultural Exports vis-a vis Asia: a post reforms Analysis. Agricultural Economics Research Review, 21: 60-66.

Singh, N.P., Kumar, R. and Singh, R.P. 2006. Diversification of Indian Agriculture: Composition, Determinants and Trade Implications. Agricultural Economics Research Review, 19(Conference No.): 23-36.

Thomas, S. and Sheikh, W. 2011. Growth and Composition of Indian agricultural Exports During Reform Era. Abhinav monthly referred. Journal of Research in Commerce and Management, 13. 